\title{
POPULATION STRUCTURE OF THE POTATO TUBER MOTH ,PHTHORIMAEA OPERCULELLA (ZELLER) , LEPIDOPTERA: GELECHIIDAE) IN DELTA EGYPT USING RAPD ANALYSIS.
}

\author{
Mohamed Elshehaby
}

Department of Zoology, Al AZhar University-branch-Assiut, Cairo, Egypt

\begin{abstract}
Little is known about the nature and extent of genetic diversity in potato tuber moth Phthorimaea operculella (Zeller), Lepidoptera: Gelechiidae). Analysis of amplified fragment length polymorphism (AFLP) has the potential to become a powerful new DNA fingerprinting technique for studying genetic relationships and genetic diversity in insects. Random amplified polymorphic DNA polymerase chain reaction (RAPD-PCR)was used to examine variation in three governorates in the Delta of Egypt. The objective of this study was to provide baseline information on the population structure of potato tuber worm in Egypt. The applicability of CTAB -based DNA extraction protocol provided suitable for AFLP analysis. Potato tuber worm adults were collected from potato fields in the major production regions in the Egypt. We used 20 random 10-oligomer primer individuals and 179 polymorphic AFLP bands were used to infer the geographic population structure of potato tuber worm. This study provides baseline data for the molecular characterization of potato tuber worm populations, which will aid in tracking the origin of future invasions within Egypt.
\end{abstract}

Keywords: DNA extraction, amplified fragment length polymorphism, insects

\section{INTRODUCTION .}

Potato tuber moth (PTM), Phthorimaea operculella (Lepidoptera: Gelechiidae) Zeller is a widely distributed, devastating pest of potatoes (Solanum tuberosum L. in the tropics and subtropics) attacking the foliage and infest the tubers in both field and store causing serious economic damage (Sudeep et.al .,2005). Larvae damage potatoes by tunneling tubers and mining leaves, stems, and petioles when in the larval stage. The patterns of population increase and range of expansion of this pest suggest that potato tuberworm populations are overwintering in this area rather than recolonizing or being reintroduced from a moderate latitude. There is no information regarding how or when exactly potato tuberworm arrived in the Egypt. The only piece of information regarding this issue is the records of potato tuber worm collections in California (Chittenden 1913, Radcliffe 1982, Jensen et al. 2005, Rondon et al. 2007, Rondon 2010). The analysis of genetic variation using DNA fingerprinting techniques has become an important approach in taxonomic, population genetic and evolutionary studies of a variety of insect species .The most frequently used DNA markers include restriction fragment length polymorphisms (RFLPs) of mitochondrial or nuclear DNA,DNA fingerprinting of microsatellite or minisatellite sequences ,standard polymerase chain reaction (PCR) and random amplified polymorphic DNA (RAPD)analysis of molecular technique nuclear .A diverse array of molecular technique available for high -resolution genetic studies of population level processes .Random amplified polymorphic DNA polymerase chain reaction (RAPD-PCR) using a single primer ,simultaneously amplifies many regions of genomic DNA (Williams et al ., 1990). RAPD is being used as a reliable technique for distinguishing insect. Amplified fragment length polymorphisms (AFLP) were used to determine the genetic population structure of potato tuberworm within the United States. (Medina .et.al.2010) Genetic population structure is often observed in insects with a wide geographic distribution (Roderick 1996, Mynhardt et al. 2007). Information on a pest's genetic population structure is important because it provides insights into levels of gene flow across a pest's geographic distribution. Genetic characterization of pest populations across their geographic distribution is needed to generate baseline information that may allow us to pinpoint the origin of future pest introductions. Thus, the objective of this study was to determine the population structure of potato tuberworm in the Delta Egypt to provide such baseline information. 


\section{MATERIAL AND METHODS}

Insects collected in three governorates Dakahlia, Gharbia and Behaira (i.e ., from the three different locations) The strains of the potato tuber moth P.operculella were reared in the laboratory as described by Fenemore (1977). ), maintained at $25^{\circ} \mathrm{C}$ and $12 \mathrm{~L}: 12 \mathrm{D}$ Photoperiod.

1. DNA extraction with CTAB method (modified from Sambrook and Russell 2001) Place each $80 \mathrm{mg}$ of (frozen or equilibrated) ( larva or pupa,or adult) in a $1.5 \mathrm{ml}$ Eppendorf cup (without fluid), put label (each site or governorates) on the cup, put cups on ice.

Put fluid nitrogen in each Eppendorf cup, quickly close the lid for a short time (for preventing the sample to "jump out"), and immediately crush animals with clean pestles; then add $500 \mu$ of warmed $\left(65^{\circ} \mathrm{C}\right.$ ) $1 \%$ (or $2 \%$ ) CTAB solution. Incubate the mixture for $1 \mathrm{~h}$ at $65^{\circ} \mathrm{C}$ in the Thermomixer. Let the mixture cool down to $55^{\circ} \mathrm{C}$ (and set the Thermomixer to $55^{\circ} \mathrm{C}$ ), then add $2 \mu \mathrm{l}-10 \mu 1$ Proteinase $\mathrm{K}$ and incubate in the Thermomixer for $3-4 \mathrm{~h}$ at $55^{\circ} \mathrm{C}$ or overnight (old animals always over night). Add $500 \mu 1$ Chloroform / Isoamyl alcohol, vortex, and centrifuge for $5 \mathrm{~min}$ at $14000 \mathrm{rpm}$ (rounds per minute) (RT). After centrifugation put upper phase of each sample in a fresh cup (if individuals are very old or dirty, begin this procedure again from the start). Be cautious not to get the tiniest part of the lower phase mixed with the upper phase. Add $40 \mu \mathrm{l} \mathrm{NaAc}$ (1/10 Vol., $3 \mathrm{M}$, ph 4.8)mix and $350 \mu$ Isopropanol $\left(-20^{\circ} \mathrm{C}\right)$, shortly shake the cup, then incubate $30 \mathrm{~min}$ at $-20^{\circ} \mathrm{C}$ or overnight (old animals at least $1 \mathrm{~h}$ ) in the freezer; if not over night $\rightarrow$ cool down centrifuge in time

Centrifuge for $30 \mathrm{~min}$ at $4{ }^{\circ} \mathrm{C}$ and $14000 \mathrm{rpm}$; discard supernatant carefully with pipit.

Place the cups on ice or in a cooled rack; wash** each pellet with $300 \mu 1100 \%$ EtOH (p.a.) $\left(-20^{\circ} \mathrm{C}\right)$, then centrifuge $10 \mathrm{~min}$ at $4{ }^{\circ} \mathrm{C}$ and $14000 \mathrm{rpm}$; discard supernatant carefully with pipit. Place the cups on ice or in a cooled rack; wash** pellet with $300 \mu 170 \% \mathrm{EtOH}$ (p.a.) $\left(-20^{\circ} \mathrm{C}\right)$, then centrifuge $5 \mathrm{~min}$ at $4{ }^{\circ} \mathrm{C}$ and $14000 \mathrm{rpm}$; discard supernatant carefully with pipit.
Wash** pellet with $150 \mu 1 \quad 70 \% \mathrm{EtOH}$ (p.a.) (RT), then centrifuge $5 \mathrm{~min}$ at RT and $14000 \mathrm{rpm}$; discard supernatant carefully with pipit. Dry DNA pellet in open Eppendorf cup for $2 \mathrm{~min}$ at $50{ }^{\circ} \mathrm{C}$ (in the Thermomixer) or for at least $10 \mathrm{~min}$ (better $30 \mathrm{~min}$ ) at RT (in the flue . Resolve the pellet in PCR water or TE buffer (pH8): Give enough time for dissolving (e.g. 1 $\mathrm{h}$ in the fridge.

PCR reaction mixtures consisted of $1 \mu \mathrm{DNA}$, 2 pmol dNTPs, 0.5 pmol of each primer, $9 \mu 1 \mathrm{dd}$ $\mathrm{H} 2 \mathrm{O}, 2 \mu 1 \mathrm{10x}$ PCR buffer (without $\mathrm{MgCl} 2$ ), 2 $\mathrm{mM} \mathrm{MgCl} 2$, and $0.4 \mu 1$ of 1 unit/ $\mu$ Taq Polymerase (Q Bio Gene). PCR-Programm: ( for all the same 1) $1: 94^{\circ} \mathrm{C}$ pause $2: 94^{\circ} \mathrm{C} \quad 4 \mathrm{~min}$ 3:94 ${ }^{\circ} \mathrm{C} 1 \min 15 \sec 4: 54^{\circ} \mathrm{C} 45 \sec 5: 72^{\circ} \mathrm{C} 25$ sec 33 cycles; back to step Nr. $3 \quad 6: 72^{\circ} \mathrm{C} 1 \mathrm{~min}$ $7: 10^{\circ} \mathrm{C}$ pause. $\mathrm{PCR}$-products were checked on $1.5 \%$ agarose gels stained with ethidium bromide.

1 .Similarity coefficient Nei and Li coefficient (1979):

$$
\mathrm{S}=1-\frac{\mathrm{N} \mathrm{ab}}{\mathrm{Na}+\mathrm{N} \mathrm{b}}
$$

Where: $\mathrm{N} \mathrm{a} \mathrm{b}$ : the number of common bands in the two samples "a" and sample "b"

$\mathrm{Na}$ : the number of bands in sample "a" $\mathrm{Nb}$ : the number of bands in sample "b"

2. Commonality or sharing band ratio: (Haymer and Mc Inns, 1994)

Commonality $\%=$

No. of common bands in samples A and B .x 100

No. of total bands of both samples A and B

\section{Genetic distance.}

$$
\begin{aligned}
& \text { Genetic distance }=1-\mathrm{S} \\
& \text { where S.co: } \quad \text { Similarity coefficient }
\end{aligned}
$$

\section{Cluster analysis.}

The presence /absence of band was analyzed by Cluster analysis and principal Coordination Analysis (P.C.A) by using the MVSP version 3.10b (1985-1999) Kovach computing services. 
Table(1) The nucleotide sequences of primers used for RAPD-PCR .

\begin{tabular}{|c|c|c|c|c|c|}
\hline $\mathrm{NO}$ & primers & Sequence5,to 3" & $\mathrm{NO}$ & primers & Sequence5,to 3" \\
\hline $1-$ & Pr1 & CCC AAG GTC & $11-$ & Pr11 & GAG TCT CAG G \\
\hline $2-$ & $\operatorname{Pr} 2$ & GGT GCG GGA & $12-$ & $\operatorname{Pr} 12$ & TTA TCC CCC C \\
\hline 3- & $\operatorname{Pr} 3$ & CCA GAT GCA & $13-$ & $\operatorname{Pr} 13$ & CCC GAT TCG G \\
\hline 4- & $\operatorname{Pr} 4$ & GTG ACA TGC & $14-$ & $\operatorname{Pr} 14$ & TGC GGC TGA G \\
\hline $5-$ & $\operatorname{Pr} 5$ & TCA GGG AGG & $15-$ & $\operatorname{Pr} 15$ & ACG CAC AAC C \\
\hline $6-$ & Pr6 & AAG ACC CCT & $16-$ & $\operatorname{Pr} 16$ & GGT GAC TGT G \\
\hline 7- & Pr7 & AGA TGC AGC & $17-$ & Pr17 & CTA CTG CCG T \\
\hline $8-$ & $\operatorname{Pr} 8$ & TCA CCA CGG & $18-$ & $\operatorname{Pr} 18$ & GGA CTG CAG A \\
\hline 9- & Pr9 & CTT CAC CCG & 19- & Pr19 & ACG GCG TAT G \\
\hline $10-$ & $\operatorname{Pr} 10$ & $\begin{array}{l}\text { CAC CAG GTG } \\
\text { A }\end{array}$ & $20-$ & Pr20 & AAC GGT GAC C \\
\hline
\end{tabular}

\section{RESULTS}

After excluding bands that were not clearly identifiable that were monomorphic for the entire data set, a total of 179 polymorphic bands were scored from 20 primers .The number of polymorphic marker bands ranged from one to eight, depending on the primer. RAPD

divergence among regions (Beheira, Gharbia and Dakahlia ) were attributable to bands exhibiting variable frequencies rather than to bands exhibiting fixed differences. Several bands provided good differentiation between regions (Beheira, Gharbia and Dakahlia ) populations for example Pr1 in Beheira governorate found 3 bands and in Dakahlia governorate but absent in Gharbia governorate, The fragments had size range from 699 to $417 \mathrm{bp}$,it was noted that samples of Beheira and Dakahlia produced genomic fingerprints patterns sharing three bands .This was subsequent by the similarity coefficient, . Commonality percentage and genetic distance according to data presented in Table (3).Also observed Pr2 in Beheira governorate were 8 bands and also 8 bands in Gharbia governorate but single band in Dakahlia governorate .The amplified fragments had approximately size range 716 to $268 \mathrm{bp}$, moreover showing one common band $533 \mathrm{bp}$ among all populations under investiga- tion ,samples of Beheira and Gharbia produced genomic fingerprints sharing bands .The similarity coefficient, commonality percentage and genetic distance are presented in Tables (3) . Pr3 scored 3 bands in Beheira governorate, 4 bands in Gharbia governorate and 6 bands in Dakahlia governorate. The fragments had size range 771 to $326 \mathrm{bp}$.samples of Beheira and Gharbia sharing 3bands, Beheira and Dakahlia 3bands ,and also Gharbia and Dakahlia 4bands The similarity coefficient, commonality percentage and genetic distance are presented in Tables (3) and Fig (1) . Pr4 showed 5 band in three populations size range 374 to $190 \mathrm{bp}$, it was noted that, samples produced genomic fingerprints sharing the all bands. The similarity coefficient, commonality percentage and genetic distance presented in Tables (3) and Fig(1). Pr5 found absent in Beheira governorate, single bands in Gharbia governorate and 4 bands in Dakahlia governorate size ranged 374 to $186 \mathrm{bp}$, where one band only with molecular size 186 bp was common among their patterns. . Pr6 observed 4 bands in Beheira governorate, absent bands in Gharbia governorate and 2 bands in Dakahlia governorate. The amplified fragments had approximately sized from 351 to $198 \mathrm{bp}$.RAPD patterns produced by using Pr-6 were characterized by the presence of only one common band. Pr7was obvious that 
a total of 8 reproducible fragments appeared in three region tested of Potato tuber moth attributed single band in Beheira governorate, absent in Gharbia governorate and 7 bands in Dakahlia governorate .The fragments had approximately sized from 632 to $233 \mathrm{bp}$ and one common band ,its molecular size $466 \mathrm{bp}$. Pr8 was obvious that a total of 4 reproducible fragments appeared in all tested Potato tuber moth, Beheira and Gharbia had one common band sharing with them, Dakahlia samples of Potato tuber moth had two bands 367 and 260bp different molecular size which did not share any bands, The similarity coefficient, commonality percentage and genetic distance presented in Tables (3) and Fig(1). Pr9 found one band in Dakahlia with molecular size $618 \mathrm{bp}$, in Beheira 3bands and Gharbia 7 bands had molecular size ranged 618 to $163 \mathrm{bp}$.

The RAPD- PCR pattern of Beheira, Gharbia and Dakahlia were characterized by one common band ,but between Beheira and Gharbia had 3 common fragments with molecular sizes 468,385 and $225 \mathrm{bp}$. Pr10 amplified fragments were not detected in the three samples under study. Pr11examination of characteristic patterns of RAPD-PCR revealed 7 reproducible fragments of sample of Dakahlia only but Gharbia and Beheira did not produce fragments.Pr12, it was obvious that the tested samples of Potato tuber moth had 8 reproducible fragments of molecular size range from 769 to $278 \mathrm{bp}$,Beheira ,Gharbia and Dakahlia shared single band with molecular size $307 \mathrm{bp}$. The similarity coefficient , commonality percentage and genetic distance presented in Tables (3) and Fig(1). The amplified fragments of genomic of fingerprints $\operatorname{Pr} 13$ had molecular sizes ranged from 980 to $79 \mathrm{bp}$,total number of reproducible fragments detected in tested samples were 14 fragments, RAPDPCR patterns of Potato tuber moth samples of Beheira and Gharbia were characterized by having four common fragments with molecular size 737,635,506, and 342 bp. RAPD-PCR patterns of Beheria and Dakahlia were characterized by two common bands with molecular size as 635 and 506 bp in three samples with tested.Pr14 was obvious that the tested samples of Potato tuber moth had two common bands with molecular sizes 747 and $695 \mathrm{bp}$.moreover, a total of 11reproducible fragments appeared in all tested samples .The amplified fragments had molecular size ranged from 992 to $380 \mathrm{bp}$. Pr 15 examination of characteristic patterns of RAPD-PCR revealed 15 reproducible fragments of samples of 8 Dakahlia 4 Gharbia and 3 Beheira, and also having three common fragments.Pr16, it was obvious that the tested samples of Potato tuber moth had 14 reproducible fragments, Beheira have 5 bands, Gharbia having 4

bands and Dakahlia having 5 bands. Morever Beheira and Gharbia sharing 3 bands molecular size from 581,481 and 286 bp ,Beheira sharing Dakahlia 2 band and also Gharbia sharing Dakahlia 2 bands with molecular size 716 and 539 bp The similarity coefficient, commonality percentage and genetic distance presented in Tables (3) and Fig(1).Pr17 examination of characteristic patterns of RAPD-PCR revealed 9 reproducible fragments of samples of Beheira and Dakahlia but Gharbia did not produce fragments, Beheira and Dakahlia having 2 common bands with molecular size 1049 and 653 bp.Pr18 examination of characteristic patterns of RAPD-PCR revealed 4 reproducible fragments of sample of Dakahlia only but Gharbia and Beheira did not produce fragments. Pr19 revaled11 reproducible fragments except Gharbia was not reproducible fragments .The fragments had approximately sized from 903 to $378 \mathrm{bp}$,Samples of Beheira and Dakahlia produced genomic fingerprint patterns sharing the five bands.Pr20 examination of characteristic patterns of RAPD-PCR tested three samples Potato tuber moth ,revaled four reproducible fragments of one only sample of Dakahlia.

The total number of RAPD-PCR fragments generated by a battery of 20 primers in Beheira governorate were 66 bands, all primers reproducible fragments except Pr5,Pr10,Pr11 and Pr20 .And the number of RAPD-PCR fragments generated by a battery of 20 primers in Gharbia governorate were 44 bands, all primers reproducible except Pr1, Pr6, Pr7 Pr10, Pr17, Pr18, Pr19 and Pr20. Also of RAPD-PCR fragments generated by a battery of 20 primers in Dakahlia governorate were 73 bands all primers reproducible except Pr10.The characteristic patterns of ampli- 
fied PCR -bands were illustrated in Fig(1) and Table (2).

Measurement of genetic similarity and genetic distance among the three Potato tuber moth samples collected from different governorates:

The genetic similarity between populations representative of the different RAPD types was calculated and shown in the form of Dendrogram in Table(3) and Fig(2).

All the tested Potato tuber moth populations are grouped into two main clusters. The first cluster included Potato tuber moth populations collected from Dakahlia governorates. On the other

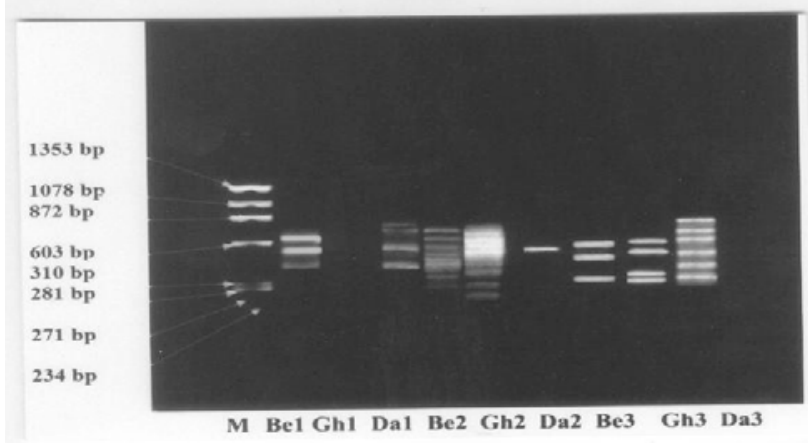

Fig(1):Nei and Li's coefficient of the relationship (Dendrogram) among Potato tuber moth collected from three governorates (Beheira,Gharbia and Dakahlia).

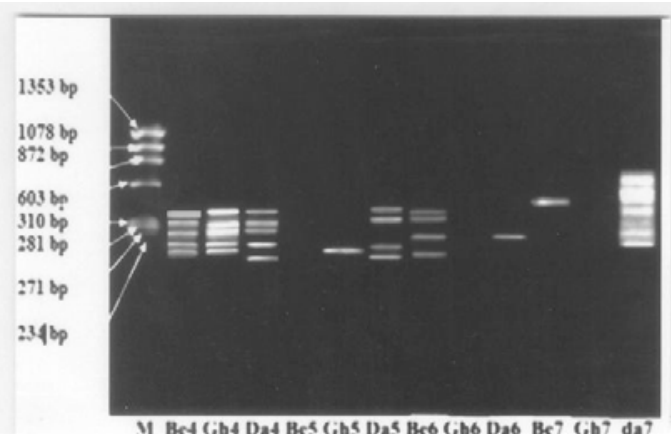

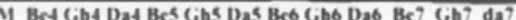
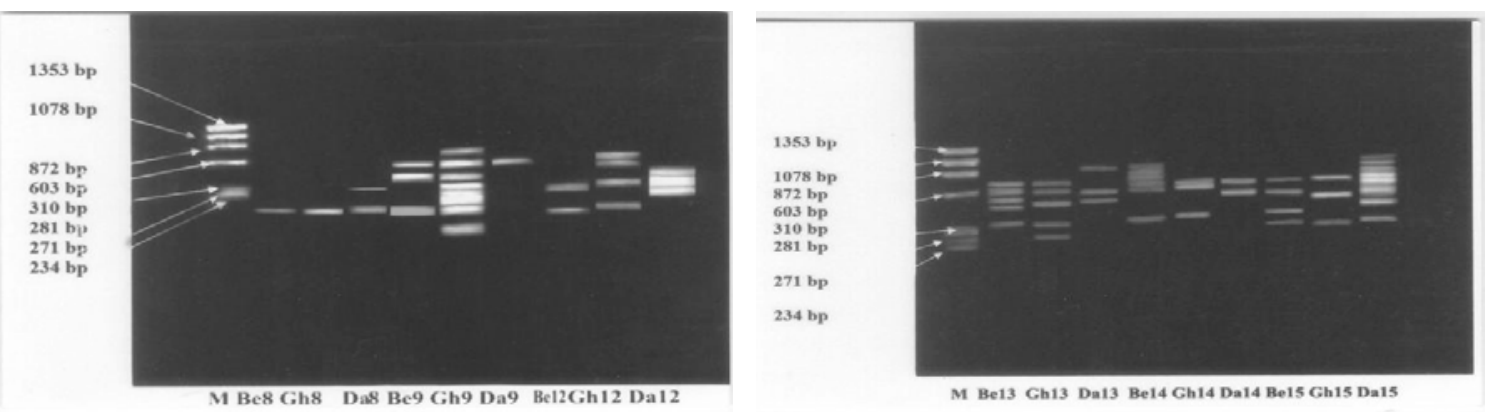

M Be13 Gh13 Da13 Be14 Gh14 Da14 Be15 Gh15 Da15
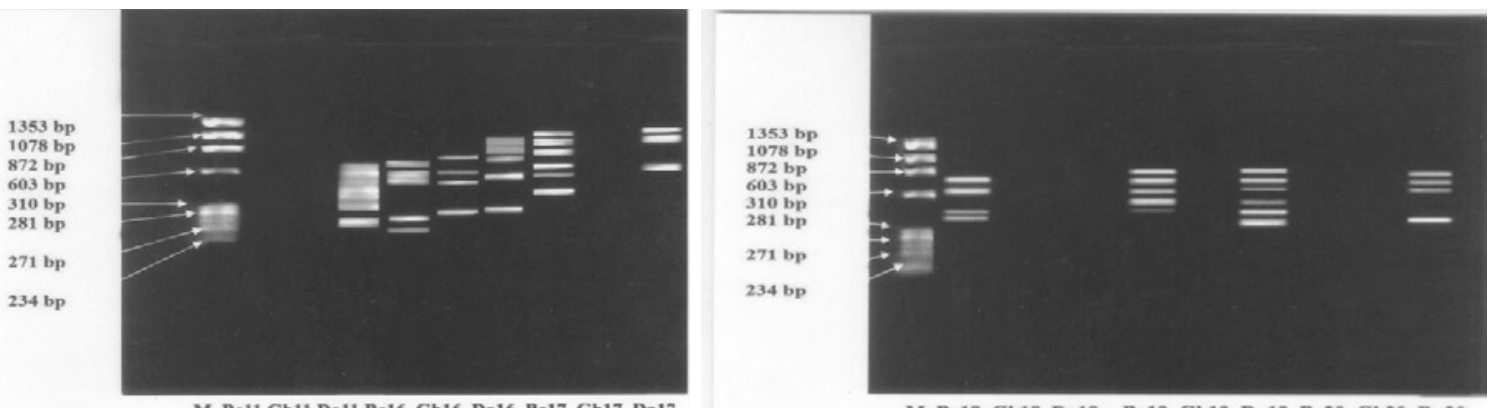

M Be18 Gh18 Da18 Be19 Gh19 Da19 Be20 Gh20 Da20

Fig (2) RAPD-PCR Patterns of three samples of Potato tuber moths collected from three different governorates using 20 primers on Beheira (Be),Gharbia (Gh) and Dakahlia(Da) respectively .Lane $M$ represents the molecular size marker.DNA sample were separated on $1.8 \%$ agarose gel and stained with ethidium bromide. 
Table( 2 ) : The total number of RAPD-PCR fragments generated by a battery of 20 primers in the three samples of Potato tuber moth collected from different governorates

\begin{tabular}{|l|l|l|l|l|}
\hline Primers & Beheira & Gharbia & Dakahlia & $\begin{array}{l}\text { Total no } \\
\text { of DNA } \\
\text { fragments }\end{array}$ \\
\hline Pr1 & 3 & - & 3 & 6 \\
\hline $\operatorname{Pr} 2$ & 8 & 8 & 1 & 17 \\
\hline $\operatorname{Pr} 3$ & 3 & 4 & 6 & 8 \\
\hline $\operatorname{Pr} 4$ & 5 & 5 & 5 & 15 \\
\hline $\operatorname{Pr} 5$ & - & 1 & 4 & 5 \\
\hline $\operatorname{Pr} 6$ & 4 & - & 1 & 6 \\
\hline $\operatorname{Pr} 7$ & 1 & - & 6 & 7 \\
\hline $\operatorname{Pr} 8$ & 1 & 1 & 2 & 4 \\
\hline $\operatorname{Pr} 9$ & 3 & 7 & 1 & 11 \\
\hline $\operatorname{Pr} 10$ & - & - & - & - \\
\hline $\operatorname{Pr} 11$ & - & - & 6 & 7 \\
\hline $\operatorname{Pr} 12$ & 2 & 4 & 3 & 9 \\
\hline $\operatorname{Pr} 13$ & 5 & 5 & 3 & 13 \\
\hline $\operatorname{Pr} 14$ & 6 & 3 & 2 & 11 \\
\hline $\operatorname{Pr} 15$ & 4 & 3 & 8 & 15 \\
\hline $\operatorname{Pr} 16$ & 5 & 4 & 5 & 14 \\
\hline $\operatorname{Pr} 17$ & 7 & - & 3 & 10 \\
\hline $\operatorname{Pr} 18$ & 4 & - & - & 4 \\
\hline $\operatorname{Pr} 19$ & 5 & - & 6 & 11 \\
\hline $\operatorname{Pr} 20$ & - & - & 4 & 4 \\
\hline & 65 & 45 & 69 & 179 \\
\hline
\end{tabular}

\section{DISCUSSION}

The use of random amplified polymorphic DNAs (RAPDs) along with microsatellites ,and new DNA analysis techniques have recently become quite popular. These methods employ an approach can be referred to as the blind analysis of DNA. RAPD-PCR technique is very important development because it means that genetic analysis can be applied on a new species without any prior knowledge about the particular DNA sequences or the genes from this new species. RAPD-PCR offers several advantages over other methods used for studying genetic variability among populations because it is not limited to a single locus but theoretically detects polymorphisms across the whole genome either coding or non coding regions ,in contradiction to isozyme markers that are limited to a few genomicregions, so that this method may be used for studying mutation among populations exposed to any mutagen (such as chemical substance, pesticides and radiation).Different parts of the genome can evolve at different rates (Nei,1987). Therefore, it is possible to show one or several regions amplified by PCR evolving at a higher

Table (3) :Similarity coefficient,commonality percentage and genetic distance among three samples of Potato tuber moth collected from three different governorates of Delta Egypt using 20 primers.

\begin{tabular}{|l|l|l|l|l|l|l|l|l|l|}
\hline & \multicolumn{3}{l}{ Similarity coefficients } & \multicolumn{3}{l|}{ Commonlity\% } & \multicolumn{3}{l|}{ Genetic distance } \\
\hline & $\begin{array}{l}\text { Be/ } \\
\text { Gh }\end{array}$ & $\begin{array}{l}\mathrm{Be} / \\
\mathrm{Dak}\end{array}$ & $\begin{array}{l}\mathrm{Gh} / \\
\mathrm{Dak}\end{array}$ & $\mathrm{Be} / \mathrm{Gh}$ & $\begin{array}{l}\mathrm{Be} / \\
\mathrm{Dak}\end{array}$ & $\begin{array}{l}\mathrm{Gh} / \\
\mathrm{Dak}\end{array}$ & $\begin{array}{l}\mathrm{Be} / \\
\mathrm{Gh}\end{array}$ & $\begin{array}{l}\mathrm{Be} / \\
\mathrm{Dak}\end{array}$ & $\begin{array}{l}\mathrm{G} / \\
\mathrm{Dak}\end{array}$ \\
\hline 1 & - & 0.57 & - & - & 42.9 & - & - & 0.43 & - \\
\hline 2 & 0.87 & 0.89 & 0.56 & 43.8 & 11.11 & 11.11 & 0.11 & 0.11 & 0.56 \\
\hline 3 & 0.57 & 0.67 & 0.6 & 42.9 & 33.33 & 40 & 0.43 & 0.33 & 0.4 \\
\hline 4 & 0.5 & 0.5 & 0.5 & 50 & 50 & 50 & 0.5 & 0.5 & 0.5 \\
\hline 5 & - & - & 0.8 & - & - & 20 & - & - & 0.2 \\
\hline 6 & - & 0.8 & - & - & 20 & - & - & 0.2 & - \\
\hline 7 & - & 0.8 & - & - & 20 & - & - & - & 0.2 \\
\hline 8 & 0.5 & - & - & 50 & - & - & 0.5 & - & - \\
\hline 9 & 0.70 & 0.75 & 0.88 & 30 & 25 & 12.5 & 0.3 & 0.25 & 0.12 \\
\hline 10 & - & - & - & - & - & - & - & - & - \\
\hline 11 & - & - & - & - & - & - & - & - & - \\
\hline 12 & 0.8 & 0.8 & 0.83 & 20 & 20 & 16.7 & 0.2 & 0.2 & 0.17 \\
\hline 13 & 0.6 & 0.77 & 0.77 & 40 & 22.22 & 32.22 & 0.4 & 0.23 & 0.23 \\
\hline 14 & 0.77 & 0.75 & 0.6 & 22.22 & 25 & 40 & 0.23 & 0.25 & 0.4 \\
\hline 15 & 0.88 & 0.69 & 0.73 & 12.5 & 30.77 & 27.3 & 0.12 & 0.31 & 0.23 \\
\hline 16 & 0.66 & 0.8 & 0.77 & 33.3 & 20 & 22.22 & 0.34 & 0.2 & 0.23 \\
\hline 17 & - & 0.77 & - & - & 22.22 & - & - & 0.23 & - \\
\hline 18 & - & - & - & - & - & - & - & - & - \\
\hline 19 & - & 0.54 & - & - & 45.45 & - & - & 0.46 & - \\
\hline 20 & - & - & - & - & - & - & - & - & - \\
\hline
\end{tabular}


rate compared with the enzymatic loci. Thus a higher variability can be obtained by RAPD-fingerprints specially if the amplified DNA regions contain micro and or minisatellites (Baruffi et al., 1995). The extensive polymorphisms detected among individuals indicate that RAPD-PCR can probably be used in a variety of ways for some species to measure clone diversity among populations and determine the degree of relatedness among individuals and races .In Random Amplified Polymorphic DNA(RAPDs),banding profiles are created using small oligonuc DNA(RAPDs), banding profiles are created using small oligonucleotide primers (around $10 \mathrm{bp}$ in length )of arbitrary sequence. The profile generated by the RAPD typing system are independent of the gene expression and not influenced by ontogenetic and environmental factors .The sensitivity of the RAPD-PCR technique was higher than the other methods of fingerprinting both in terms of the samples quantity and quality .In RAPD fingerprinting, an oligonucleotide primer amplifies distinct DNA fragments. These fragments are referred to as RAPD markers. The number and size of RAPD markers depend on the complementary sequence of particular primer and template DNA(Hedrick,1992 and Williams et al .,1990) .Numerous factors can affect the reproduce and standardization of reactions as DNA quality and quantity, $\mathrm{Mg}^{2}+$ or concentratrations and Taq polymerase source (Loxdal and lushhai 1998 ).In taxonomy and systemic ,species -specific RAPD markers could be an invaluable tool for species verification and establishing the status of organisms of controversial systematcs .Moreover ,RAPD-PCR provided an additional opportunity to judge the relative merits of isozyme and RFLP analysis. In the present study, RAPD-PCR c yield reliable and useful results, if certain points were considered .The risk of misinterpretation in RAPD analysis if different RAPD fragment have similar size ,can be minimized by the use of several RAPD markers and the reproducibility of these markers .The homology of RAPD fragments, optimization of reaction components and condition of RAPD-PCR is essential to have reproducible results. The optimization process included the use of a specific combination of template DNA and primer, the use of the standard conditions for extraction and amplification of DNA as well as the extreme care in sterilized of buffers, tubes and tips .The same finding were reported by (Virk et al ., 1995 and Dinesh et al 1993). RAPD-PCR in potato tuber moth ,phthorimaea operculella populations as in the other insects produced a serious of discrete DNA fragments which typically vary in intensity and ranged in size from $118 \mathrm{bp}$ larger than $1350 \mathrm{bp}$.In addition to several reported factors affecting reproducibility of RAPD amplification ,this study has established that different concentration of primer influence banding patterns .Genomic DNA of potato tuber moth ,phthorimaea operculella,produced more reliable banding patterns when the primers were used at concentration 20-25 pM . Virk et al., 1995) reported that the banding pattern of any genomic DNA depends mainly on the frequency of annealing sites for the primers used and on the effective concentration of such primers in the reaction tube .The number and size of amplification products depend on the complementarity of sequence of particular primer and template DNA .The present results also agree with what has been reported by (Bardakci and Skibinski 1994) ,who found that broad agreement across primers but overall level of similarity was varied between primers . Therefore, the choice of primers is of a major importance for the discriminatory power of the technique. (Foster et al., 2004., Duan et al.,2004 and Kim and Sappington .,2004 ) analyzed RAPD-PCR pattern and genetic differentiation among boll weevil populations from eighteen locations across eight US states and North-East Mexico. Sixty -seven reproducible bands from six random primers were analyzed for genetic variation within and between boll weevil population. Genetic and geographic distances among all populations were positively correlated, reflecting a pattern of isolation by distance within a larger population .Gene flow between, South-Central, Western and Eastern regions is limited, but migration between locations within regions appears to be relatively frequent up to distances $300-400 \mathrm{Km}$.In any species ,the RAPD technique amplifies some regions of DNA that are monomorphic but it simultaneously produce other bands that are identified as 
unique set of genotypes in each species. There are several explanations for the variability detected by this method. It is possible that variation is due to the presence of primer binding site in highly regions .(Sudeep et al., 2005 and Lery et al .,2003) analyzed the RAPD-PCR was used to characterize 11 insect cell lines including six from Lepidoptera (five species) one from dipteral and four from coleopteran ( one species : Leptinotarse decemlineata) .whatever the order and even when comparing two closely related species from the same genus (Spodoptera), the DNA fingerprints are different from one species or from one primer to the another .On the other hand ,two independently isolated cell lines from the lepidopteran Phthorimaea operculella produce nearly identical profile with only minor differences .Finally ,a statistical analysis based on Nei $\square$ s similarity coefficient .Each possesses a common recognizable pattern was found in filed collected. While showing also a series of a polymorphic markers which allow one to distinguish each cell line from the three other RAPD Fingerprinting. The present results reveal that RAPD are effective markers in determining polymorphism and estimating the variability and genetic distance between the studied potato tuber moth samples .The differential amplification may be due to sequence difference in the priming sites ( Williams et al., 1990 and Sultmann .,1995) or due to point mutation, which allow or abolish primer binding (Hedrick ,1992). Thus the polymorphisms are essentially due to differences in frequency and distribution of priming sites .However, the specific interpretation of polymorphisms obtain by RAPD technique is yet open to discussion. Our results are harmony with this trend, where in the present study three populations from different governorates were tested .All the tested populations are grouped into main clusters. The first cluster included potato tuber moth populations from Beheira and Gharbia .The second grouped included potato tuber moth populations of Dakahlia governorates. The above conclusion was conducted from cluster analysis and Principal Coordination Analysis (P.C.A) to verify that the results did not depend on type of statistical analysis used statistical data of P.C.A confirmed that the cluster analysis. RAPD have provided new and useful information, which will assist further research on this important agricultural pest .The results presented here demonstrate the use of the RAPD technique, which may have application in studies of other populations.

\section{REFERENCES}

Bardakei ,F. and Skibininski, D.O.(1994).Application of the RAPD technique in Tiliapia fish:species and subspecies identication.Heredity ,73:117-123.

Baruffi,L .;Damini,G.; Guglielmino ,C. R. ; Bandis ,C; Malacida ,A.R. and Gasperi,G (1995). Polymorphism within and between populationsof Ceratitis capitata : comparsion between RAPD and multilocus enzyme electrophoresis data.Heredity.74:425-437.

Chittenden, F. H. (1913). The potato tubermoth. U.S. Dept. Agric. Farmer $\square$ s Bull. 557: 1-7.

Dinesh,K.R.;Lim ,T.M.;Chua ,K.L.;Chau,W.K. and Phang ,V.P.E.(1993).RAPD analysis :An efficient method of DNA fingerprinting in fishes.Zoo.Sci.,10:849-854.

Duan ,Y.;Kerdelhue ,C.;Ye,H.and Lieutier ,F (2004). Genetic studz of the forest pest Tomicus pinperda (Col.,Scolytinae) in Yunnan province (China)compared to Europe :New insights for the systematic and evolution of the genus Tomicus.Heredity.93:416-422.

Fenemore,P.G. (1977). Oviposition of the potato tuber moth, Phthorimaea operculella (zeller) ( lepidotera: Gelechiidae);Fecundity in relation to mated state,age , pupal and weight.J.Zoo.4:187-191.

Foster,B.T.; Cognato,A.I.and Gold ,R.E. (2004).DNAbased identification of the eastern subterranean Termite reticulitermes flavipes (Isoptera: Rhinotermitidae ).J.Econ.Entomol.97(1) 95-101.

Haymer ,D.S.and McInnis ,D.(1994).Resolution of populations of the Mediterranean fruit fly at the DNA level using random primers.Genome .37:244-248.

Hedrick ,K.F.(1988). Shooting the RAPDs.Nature,355.679680.

Hedrick,P (1992).Genetics of populations .72-73

Jensen, A., P. Hamm, A. Schreiber, and S. DeBano.( 2005). Prepare for tuber moth in 2005. Potato Progress. 5: 1-4.

Kim ,K.S. and Sappington ,T.W (2004).Genetic structuring of boll weevil populations in US based on RAPD markers .Insec.Molec.Biol.13 (3) 293-303.

Lery .X .; LaRue. B.; Cossette .J .; and Charpentier .G.(2003). Characterization and authentication of insect cell lines using RAPD markers.Insec. Bioch. And mol. Boil.(33)1035-104.

Loxdal ,H.D.and Lushai,G.(1998).Moleclar markers in Entomology (Review article ).Bull.Entomol.Res.88:577600.

Medina.R.F; Rondon.S.I; Reyna.S.M.;,1 and Dickey.A.M. 
(2010) Population Structure of Phthorimaea operculella (Lepidoptera: Gelechiidae) in the United States. Environmental Entomology.39(3):1037- 1042.

Mynhardt, G., M. K. Harris, and A. I. Cognato.( 2007). Population genetics of the pecan weevil ( Coleoptera: Curculionidae) inferred from mitochondrial nucleotide data. Ann. Entomol. Soc. Am. 100: 582-590.

Nei, M. and Li, W. (1979). Mathematical model for studying genetic variation in terms of restriction endonucleasea, Proc. Nat. Acad. Sci. U. S. A., (76) 5269 - 5273.

Nei,M(1987).Molecular evolutionary genetics .Columbia UnivesityPress ,New York.

Radcliffe, E. B.( 1982). Insect pest of potato. Annu. Rev. Entomol.27: 173-204.

Roderick,G.K (1996).Geographic structure of insect populations :gene flow, phylogeography,and their uses. Annu. Rev.Entomol 41:325-352.

Rondon, S. I.(2010). The potato tuberworm: a literature review of its biology, ecology, and control. Am. J. Potato Res. 87: 149-166.

Rondon, S. I., G. H. DeBano, P. B. Clough, A. Hamm, A. Jensen, J. M. Schreiber, M. Alvarez, J. Thornton, J. D. Barbour, and M. Dogramaci. 2007. Biology and management of the potato tuberworm in the Pacipc Northwest.PNW 594: 1-8.

Sambrook, J.; Russell, D. W. (2001). Molecular Cloning: A Laboratory Manual.Cold Spring Harbor Laboratory Press, Cold Spring Harbor, New York.

Sudeep.A.B; Khushiramani.R; S.S. Athawale.S.S; Mishra. A.C and Mourya.D.T.(2005) Characterization of a newly established potato tuber moth (Phthorimaea operculella Zeller) cell line.Indian J Med Res 121: 159-163.

Sultmann, H.; Mayer,W.E;Figueroa,F.; Tichy,H . and Klein ,J.(1995).Phylogenetic analysis of Cichlid fishes using nuclear DNA markers .Mol.Biol.12:1033-1047.

Virk,P.S.;Ford-leoyed, B.V.;Jackson ,M.T.and Newburry ,H.J. (1995).Use of RAPD for RAPD for the study of diversity within plant germplas collections .Heredity 74:170-179.

Williams ,J. G.K; Kubelik ,A. R; Livak, K.J; Rafalski ,J. A and Tingey, S.V.(1990).DNA polymorphisms amplified by arbitrary primers are useful as genetic markers .Nucl .Acid Res.,18,6531-6535

Hedrick,P (1992).Genetics of populations .72-73

Haymer ,D.S.and McInnis ,D.(1994).Resolution of populations of the Mediterranean fruit fly at the DNA level using random primers.Genome .37:244-248.

Sultmann, H.; Mayer,W.E;Figueroa,F.; Tichy,H . and Klein ,J.(1995).Phylogenetic analysis of Cichlid fishes using nuclear DNA markers .Mol.Biol.12:1033-1047.
Williams J. G .K.; Kubelik, A . R.; Livak, K . J.; Rafalski , J. A. and Tingey, S. V. (1990). DNA polymorphisms amplified by arbitrary primers are useful as genetic markers .Nucl. Acids Res., 18:6531-6535.

Lery .X .; LaRue. B.; Cossette .J .; and Charpentier .G.(2003). Characterization and authentication of insect cell lines using RAPD markers.Insec. Bioch. And mol. Boil.(33)1035-104.

Kim ,K.S. and Sappington ,T.W (2004).Genetic structuring of boll weevil populations in US based on RAPD markers .Insec.Molec.Biol.13 (3) 293-303.

Duan ,Y.;Kerdelhue ,C.;Ye,H.and Lieutier ,F (2004). Genetic studz of the forest pest Tomicus pinperda (Col.,Scolytinae) in Yunnan province (China)compared to Europe :New insights for the systematic and evolution of the genus Tomicus.Heredity.93:416-422.

Foster,B.T.; Cognato,A.I.and Gold ,R.E. (2004).DNAbased identification of the eastern subterranean Termite reticulitermes flavipes (Isoptera: Rhinotermitidae ).J.Econ.Entomol.97(1) 95-101.

Bardakei ,F. and Skibininski, D.O.(1994).Application of the RAPD technique in Tiliapia fish:species and subspecies identication. Heredity ,73:117-123.

Dinesh,K.R.;Lim ,T.M.;Chua ,K.L.;Chau,W.K. and Phang ,V.P.E.(1993).RAPD analysis :An efficient method of DNA fingerprinting in fishes.Zoo.Sci.,10:849-854.

Virk,P.S.;Ford-leoyed, B.V.;Jackson ,M.T.and Newburry ,H.J. (1995).Use of RAPD for RAPD for the study of diversity within plant germplas collections .Heredity 74:170-179.

Loxdal ,H.D.and Lushai,G.(1998).Moleclar markers in Entomology (Review article ).Bull.Entomol.Res.88:577600 .

Sambrook, J.; Russell, D. W. (2001). Molecular Cloning: A Laboratory Manual.Cold Spring Harbor Laboratory Press, Cold Spring Harbor, New York.

Williams J. G .K.; Kubelik, A . R.; Livak, K . J.; Rafalski , J. A. and Tingey, S. V. (1990). DNA polymorphisms amplified by arbitrary primers are useful as genetic markers .Nucl. Acids Res., 18:6531-6535.

Hedrick ,K.F.(1988).Shooting the RAPDs.Nature,355.679680.

Fenemore,P.G. (1977). Oviposition of the potato tuber moth, Phthorimaea operculella (zeller) ( lepidotera: Gelechiidae);Fecundity in relation to mated state,age, pupal and weight.J.Zoo.4:187-191.

Jensen, A., P. Hamm, A. Schreiber, and S. DeBano.(2005). Prepare for tuber moth in $2005 . \quad$ Potato Progress. 5: 1-4.

Radcliffe, E. B.( 1982). Insect pest of potato. Annu. Rev. Entomol.27: 173-204.

Chittenden, F. H. (1913). The potato tubermoth. U.S. Dept. Agric. Farmer $\square$ s Bull. 557: 1-7. 
Sudeep.A.B; Khushiramani.R; S.S. Athawale.S.S; Mishra. A.C and Mourya.D.T.(2005) Characterization of a newly established potato tuber moth (Phthorimaea operculella Zeller) cell line.Indian J Med Res 121: 159-163.

Medina.R.F; Rondon.S.I; Reyna.S.M.;,1 and Dickey.A.M. (2010) Population Structure of Phthorimaea operculella (Lepidoptera: Gelechiidae) in the United States. Environmental Entomology.39(3):1037- 1042.

Williams ,J. G.K; Kubelik ,A. R; Livak, K.J; Rafalski ,J. A and Tingey ,S.V.(1990).DNA polymorphisms amplified by arbitrary primers are useful as genetic markers .Nucl .Acid Res.,18,6531-6535.

Rondon, S. I., G. H. DeBano, P. B. Clough, A. Hamm, A. Jensen, J. M. Schreiber, M. Alvarez, J. Thornton, J. D. Barbour, and M. Dogramaci. 2007. Biology and management of the potato tuberworm in the Pacipc Northwest.PNW 594: 1-8.

Roderick,G.K (1996).Geographic structure of insect populations :gene flow, phylogeography,and their uses. Annu. Rev.Entomol 41:325-352.
Nei, M. and Li, W. (1979). Mathematical model for studying genetic variation in terms of restriction endonucleasea, Proc. Nat. Acad. Sci. U. S. A., (76) 5269 - 5273.

Mynhardt, G., M. K. Harris, and A. I. Cognato.( 2007). Population genetics of the pecan weevil ( Coleoptera: Curculionidae) inferred from mitochondrial nucleotide data. Ann. Entomol. Soc. Am. 100: 582-590.

Baruffi,L .;Damini,G.; Guglielmino ,C. R. ; Bandis ,C; Malacida ,A.R. and Gasperi,G (1995). Polymorphism within and between populationsof Ceratitis capitata : comparsion between RAPD and multilocus enzyme electrophoresis data.Heredity.74:425-437.

Nei,M(1987).Molecular evolutionary genetics .Columbia UnivesityPress ,New York.

Rondon, S. I.( 2010). The potato tuberworm: a literature review of its biology, ecology, and control. Am. J. Potato Res. 87: 149-166. 